3 Running title: Aphid-plant interactions under drought stress

4 Abstract

6 Aphids are abundant in natural and managed vegetation, supporting a diverse

\section{Stressful times in a climate crisis: how will aphids respond to more frequent drought?}

community of organisms and causing damage to agricultural crops. Using a meta-

analysis approach, we aimed to advance understanding of how increased drought

incidence will affect this ecologically and economically important insect group, and to characterise the underlying mechanisms.

\section{Location}

\section{Global.}

\section{Time period}

1958-2020.

\section{Major taxa studied}

Aphids.

\section{Methods}

We used qualitative and quantitative synthesis techniques to determine whether drought stress has a negative, positive, or null effect on aphid fitness. We examined these effects in relation to 1) aphid biology, 2) the aphid-plant. species combination. We compiled two datasets: 1) a "global" dataset ( $n=55$ from 55 published studies) comprising one pooled effect size per study, and 2) an "expanded" dataset $(n=93)$ containing multiple datapoints per study, separated into different measures of aphid fitness but pooled across aphid-plant combinations. Where reported, we extracted data on the effect of drought on plant vigour, and plant tissue concentrations of nutrients and defensive compounds, to capture the potential causes of aphid responses.

\section{Results}


29 Across all studies ("global" dataset), drought stress had a negative effect on aphid

30 fitness: Hedges' $\mathrm{g}=-0.57 ; 95 \%$ confidence interval $\left(\mathrm{Cl}_{95}\right)= \pm 0.31$. The "expanded"

31 dataset indicated that, on average, drought stress reduced aphid fecundity $(\mathrm{g}=$ -

32 0.98; $\left.\mathrm{Cl}_{95}= \pm 0.50\right)$ and increased development time $\left(\mathrm{g}=1.13 ; \mathrm{Cl}_{95}= \pm 1.02\right)$.

33 Furthermore, drought stress had a negative impact on plant vigour ( $\mathrm{g}=-7.06$; $\mathrm{Cl}_{95}=$

$34 \pm 2.86)$ and increased plant concentrations of defensive chemicals $\left(\mathrm{g}=3.14 ; \mathrm{Cl}_{95}=\right.$

$35 \pm 3.14)$.

\section{Main conclusions}

37 Aphid fitness is typically reduced under drought, associated with reduced plant 38 vigour and increased chemical defence in drought-stressed plants. We propose a 39 conceptual model to predict drought effects on aphid fitness in relation to plant vigour 40 and defence.

41 Keywords: Climate change, Ecological entomology, Insect-environment 42 interactions, Meta-analysis, Plant-insect interactions 


\section{Introduction}

The changing climate is anticipated to lead to decreased annual levels of precipitation in some regions, resulting in extended periods of drought (Blenkinsop \& Fowler 2007; Santos, Belo-Pereira, Fraga \& Pinto 2016). For plants in mesic habitats, prolonged drought can have severe consequences on plant physiology, often leading to reduced growth and photosynthetic capacity (Osakabe, Osakabe, Shinozaki \& Trans 2014; Zeppel, Wilks \& Lewis, 2014). Plant physiological responses to drought can directly influence the population dynamics, fitness, phenology, and biology of herbivorous insects (Stayley et al., 2006; Huberty \& Denno 2004; Mody, Eichenberger \& Dorn, 2009; Aslam, Johnson \& Karley, 2013), with consequences that cascade through trophic networks (Johnson, Stayley, McLeod \& Hartley, 2011; Rodríguez-Castañeda 2013). Meta-analysis provides a useful approach to predict the direction of drought effects on insect herbivores, reporting an overall response that accommodates between-study variation.

Previous meta-analyses have examined drought effects by comparing responses of herbivorous insect species with different feeding strategies (Koricheva \& Larsson, 1998; Huberty \& Denno 2004). To date, however, there has been no comprehensive assessment of drought effects on a specific herbivore group and the underpinning causes due to physiological changes in the host plant. Aphids are phloem-feeding insects of global ecological importance (Van Emden \& Harrington 2017) as abundant components of insect communities in diverse ecosystems across the globe (Messelink, Sabelis \& Janssed, 2012; Roubinet et al., 2018). There are over 4,400 known species of aphid (Blackman \& Eastop 2000) and around 250 of these are major agricultural and horticultural pests, making them an economically important group of herbivorous insects. In many ecosystems, aphids sustain several higher trophic groups, including their primary consumers, such as parasitoid wasps, spiders, ladybirds, and carabid beetles (Staudacher, Jonsson \& Traugott, 2016), the higher-level consumers of these aphid natural enemies, such as hyperparasitoids (Traugott et al., 2008; Lefort et al., 2017), small mammals and birds, and many entomological pathogens and parasites (Hagen \& van den Bosch 1968). Examining how climate change, including drought, might influence aphid fitness is a major avenue of current research, specifically with regards to examining how this might affect the productivity and functioning of agricultural, horticultural, and natural 
77 vegetation systems across the globe (Romo \& Tylianakis 2013; Teixeira, Valim,

78 Oliveira \& Campos, 2020)

Analysis of sap-feeding insects by Huberty \& Denno (2004) suggested that drought has an overall negative effect on the fitness of sap-feeding insects. Experimental studies of aphids indicate that this negative effect of drought is observed across many aphid-plant systems (Pons \& Tatchell 1995; Agele, Ofuya \& James, 2006; Mody et al., 2009; Aslam et al., 2013; Grettenberger \& Tooker 2016; Foote, Davis, Crowder, Bosque-Pérez \& Eigenbrode, 2017), although this has not been assessed quantitatively. Further, there has been no comprehensive analysis of the causes of decreased aphid fitness under drought, although several studies suggest that it is mediated through reduced plant fitness (Hale, Bale, Pritchard, Masters \& Bworn, 2003; Banfield-Zanin \& Leather, 2015; Dai, Liu \& Shi, 2015). Two meta-analyses conducted in recent decades provide context for constructing a hypothesis to explain variation in aphid fitness under water stress in relation to plant fitness. First, Huberty \& Denno (2004) found little evidence for the plant stress hypothesis (i.e. enhanced insect performance on water-stressed host plants due to increased tissue nitrogen availability: White, 1969) amongst sap-feeding insects (phloem and mesophyll feeders). Second, Cornelissen, Fernandes \& Vasconcellos-Neto (2008) examined insect fitness in relation to plant vigour and demonstrated that sap-feeding insects are more abundant and show increased fitness when feeding on more vigorously growing plants. These findings lead us to hypothesise that the effects of drought on aphid fitness are driven by decreased plant vigour, such as reduced plant growth rate or mass (Hatier et al., 2014), rather than stress-related changes in plant nutritional quality.

Although many studies have reported reduced aphid fitness when exposed to drought stressed hosts (Banfield-Zanin \& Leather, 2015; Dai et al., 2015; Foote et al., 2017), studies have reported null (Mewis, Khan, Glawischnig, Schreiner \& Ulrichs, 2012) and positive (Oswald \& Brewer, 1997) effects. Multiple factors could explain these contrasting observations, including differences in aphid or plant biology. Indeed, in the study by Oswald \& Brewer a positive effect of drought on aphid fitness was detected in the Russian wheat aphid, Diuraphis noxia (Mordvilko), and a negative effect was reported for the corn leaf aphid, Rhopalosiphum maidis (Fitch). Although both species are cereal-feeding aphids, $D$. noxia and $R$. maidis 
110

belong to two distinct aphid tribes, the Macrosiphini and the Aphidini, respectively (Kim \& Lee, 2008; Choi, Shin, Jung, Clarke \& Lee, 2018), raising the possibility that differences in aphid biology and/or life history could underlie the contrasting responses. Additionally, the specific aphid-plant combination could further influence the effects of drought on aphid fitness. For example, multiple aphid species exhibit contrasting responses to drought on a common host plant (Mewis et al.) and a single aphid species can display contrasting responses on related host plant species (Hale et al., 2003). These findings suggest that aphid responses to drought could be mediated by plant species-specific responses to drought (i.e. the availability of nutrients, the concentration of defensive compounds, resource allocation to new tissue). Understanding these mechanisms is necessary to predict the outcomes of plant-insect interactions under a changing climate.

Here, we take the novel approach of analysing data on aphid fitness and host plant physiology, using studies comparing drought with unstressed conditions, to examine the hypothesis that changes in aphid fitness are driven by the effects of drought on plant vigour. We predicted that reduced aphid fitness would be associated more strongly with decreased plant vigour (e.g. decreased mass, reduced growth) under drought than with changes in plant nutritional quality or defensive chemistry. Initially, we carry out a literature synthesis and take a "vote-counting" approach to qualitatively determine whether drought has an overall negative, positive, or null effect on aphid fitness. Following this, we use meta-analysis techniques to quantify these effects. Next, we extract data reporting on plant physiological responses to drought, including measurements of plant vigour, and tissue concentrations of plant nutrients and plant defensive compounds. This provides us with data that can be used, for the first time, to quantify drought effects on plant physiology in parallel with aphid fitness responses. A secondary aim of the meta-analysis was to explore patterns in aphid responses to drought in relation to 1) aphid tribe or aphid host range, and 2) the aphid-plant system (i.e. species combinations) to identify any common features of aphid biology that explain variation in aphid fitness responses to drought. The mechanistic understanding provided by our study allows the effects of drought on herbivore success to be anticipated for phloem-feeding insects across different habitats under future climatic conditions.

\section{Literature search and meta-analysis}




\section{Criteria for inclusion in analysis}

144 The search terms "Drought" AND "Aphid" were used to conduct a literature search of 145 both the Web of Science and Scopus databases (with a publication cut-off date of 146 September 2020), to maximise the number of studies included (the overlap between 147 them is only 40-50\%: Nakagawa, Noble, Senior \& Lagisz, 2017). 190 papers were 148 identified from the Web of Science database and 197 from the Scopus database. 149 After removing duplicates, 247 published papers were extracted. A previous meta150 analysis which examined insect responses to drought (Huberty \& Denno, 2004) was 151 screened and an additional 16 studies were identified. This produced a pool of 263 152 studies published between 1958 and 2020. See Fig. 1 for the PRISMA flow diagram, 153 constructed following Moher, Liberati, Tetzlaff \& Altman (2009). To be considered for 154 inclusion in the analysis, papers had to satisfy the following criteria: 1 ) to be primary 155 literature presenting data on the responses of at least one aphid species to drought 156 relative to an unstressed control treatment; 2) report aphid responses as the effect of 157 drought on a measure of aphid fitness; 3) present the responses so that an 158 estimation of the treatment differences could be determined alongside an estimate of 159 the variation. A total of 55 studies satisfied these criteria. A further 26 studies 160 reported data for aphid fitness but did not display the data; these studies were excluded from the meta-analysis but included in qualitative "vote-counting" assessment. The full range of studies are detailed in Appendix 1 and Appendix 2.

Heterogeneity is routinely expected and accepted in meta-analyses (Higgins, 2008).

164 Acceptance of heterogeneous data is dependent on whether the inclusion criteria are 165 sound and the underlying data correct (Higgins). Extracted data were assessed for 166 heterogeneity by measuring Cochran's $Q$.

\section{Data extraction and pooling: aphid responses}

168 Aphid fitness data were extracted from drought and control (unstressed) treatments. 169 Where reported, the mean value and an indication of the variation around the mean were extracted using WebPlotDigitizer v.4.2 (Rohatgi, 2019. Weblink: https://automeris.io/WebPlotDigitizer). Where median and interquartile ranges were reported, means and standard deviation were estimated following Luo, Wan, Liu \& Tong (2018) and Wan, Wang, Liu \& Tong (2014). Data were extracted for the following aphid fitness parameters: fecundity (daily, lifetime, and mean fecundity and 
175 life-history parameters related to reproduction, such as the intrinsic rate of increase),

176 population size or aphid density/abundance, aphid development (time until adulthood 177 and time until first reproduction), aphid biomass, or aphid lifespan. The effect size 178 (Hedges' g; Cooper, Hedges, Valenting, 2019) was calculated from aphid responses 179 under drought relative to aphid responses under control conditions. Hedges' g was 180 selected as this parameter performs better across studies with a lower sample size, 181 when compared with Cohen's D or Glass's Delta. Where multiple drought treatments 182 were imposed, data were extracted from the control and the most severe drought 183 treatment.

Where multiple formats of a fitness parameter were reported (e.g. fecundity reported in terms of mean fecundity and lifetime fecundity) data were pooled across different measures of the core parameter to provide one response per parameter assessed. Data were further pooled across any other experimental treatments imposed in the study (for example, in Xing et al. (2003) drought and control conditions were pooled across three $\mathrm{CO}_{2}$ treatments), and within aphid species to provide one data point per aphid species per fitness parameter. Data were collated separately for each host plant species. This pooling method produced 93 unique data points over the 55 studies.

Two datasets were compiled based on these data. In the "global" dataset (see Supplementary Fig. 1A for the associated funnel plot), data were pooled within each study across fitness parameters, plant hosts, and aphid species to produce 55 data points, i.e. one pooled effect size per study, reporting the overall aphid responses to drought. Within the "global" dataset, the calculated hedges' $g$ values for developmental fitness parameters were converted from positive to negative values to align with the net direction of other fitness parameters (this was required because a positive hedges' $g$ value for development represents a fitness decrease, compared with the other parameters for which a fitness decrease would result in a negative hedges' $g$ value). In the "expanded" dataset (see Supplementary Fig. 1B for the associated funnel plot), effect sizes were calculated separately for each fitness parameter and aphid-host plant combination in the study. To ensure that the direct comparison of different aphid fitness parameters was justified for inclusion in the analysis, the calculated hedges' $g$ values for each data point were plotted 
into categories. Furthermore, to avoid potential pseudo-replication resulting from extracting multiple fitness parameters per study, the study number was included as a random term in all analyses of the "expanded" dataset.

\section{Grouping of extracted data: aphid responses}

Extracted data contained information on 23 aphid species (Table 1). To disentangle any potential taxonomic differences, data were categorised into three groups: a "Tribe" grouping based on the taxonomic tribe of the aphid species; an "Aphid Host Range" category based on whether the aphid species is a specialist or generalist feeder; and a "Plant-Aphid" group based on the plant-aphid system examined. Categorisations for Tribe and Aphid Host Range are detailed in Table 1. The final Tribe grouping used in the "expanded" dataset comprised Macrosiphini $(n=60)$, Aphidini $(n=23)$, and others $(n=10)$, while the aphid host range grouping comprised Specialist $(n=62)$ and Generalist $(n=31)$ categories.

Extracted data covered 24 host plant species. To facilitate comparison between plant-aphid combinations, data were grouped into the following plant host categories: Brassicas (comprising Brassica oleracea and B. napus, $\mathrm{Bn}: n=6$ and 15 from the "global" and "expanded" datasets, respectively), Cereals (Arrhenatherum elatius, Dactylis glomerate, Holcus lanatus, Hordeum vulgare, Triticum aestivum: $n=20$ and 38), Forage species (Chenopodium sp., Festuca arundinacea, Medicago sativa, Lolium perenne, L. multiforum, Poa autumnalis, Rumex sp.:: $n=7$ and 10), Legumes (Pisum sativum, Glycine max: $n=2$ for both datasets), Model Arabidopsis species (Arabidopsis thaliana: $n=3$ and 4), Solanum sp. (Solanum tuberosum, $S$. lycopersicum: $n=4$ and 9), and Tree systems (Malus domestica, Picea abies, P. sitchensis, P. Sylvestris, Populus sp., $n=13$ and 15).

\section{Criteria for inclusion in analysis, data pooling, and data grouping: plant} responses

Studies were screened for inclusion in an additional meta-analysis to determine the impact of drought on the host plant. To be considered for inclusion, studies had to satisfy the following criteria: 1) present data on the responses of at least one plant species to drought relative to a controlled condition; 2) report responses as the effect of drought on either a measure of vigour (including mass, height, and growth), tissue nitrogen $(\mathrm{N})$ or amino acid concentration, or plant chemical defence (e.g. secondary 
240

metabolite or phytohormone concentration); 3) report an estimation of the differences alongside the variation. From the pool of 55 studies, 32 reported effects of drought on plant vigour (i.e. dry matter accumulation, plant growth, and leaf/tiller production), 12 reported a measure of tissue $\mathrm{N}$ or amino acid concentration, and ten reported tissue defensive compound concentrations. The effect size (Hedges' g) was calculated as described above. Data were pooled at the study level into measures of vigour, $\mathrm{N}$ or amino acid concentration, and defensive compound concentrations, resulting in three plant sub-datasets: vigour, nutritional, and defensive.

\section{Measuring publication bias}

Funnel plots were created to test for publication bias and a rank correlation test was carried out to test for funnel plot asymmetry (Supplementary Fig. 1). Additionally, as most null results go unpublished, failsafe analysis using Orwin's method (Orwin, 1983) was employed to estimate the number of studies reporting a null effect that would be required to reduce the observed average effect size to -0.1 . This analysis estimated $n=261$ and $n=2228$ null studies required to reduce the observed average effect size to -0.1 in the aphid and plant datasets, respectively.

\section{Analysis of extracted data}

Statistical analysis was carried out using $R$ version 4.0.3, with additional packages ggplot2 v.3.3.2 (Wickham, 2016), meta v.4.15-1, and metafor v.2.4-0. A total of 81 and 55 studies were included in the vote counting and meta-analysis, respectively (detailed in Appendix 1 and Appendix 2).

To account for variation between different methodologies used to implement drought, drought methodology was allocated into one of five categories: FC (studies where \% reduction in field capacity was used); DI (studies where decreased volume of irrigation was used); GM (studies which used a gravimetric method to adjust irrigation); CC (studies which used a calibration curve to help advise water irrigation regimes); and RW (studies where irrigation was simply restricted or withheld from the drought treated plants). The effect of these drought treatments on aphid fitness was examined to confirm that different methodologies used to initiate drought did not vary in their effects (Supplementary Fig. 3).

\section{Aphid response analysis: Vote counting procedure}


271 Briefly, studies were screened for whether a significant effect of drought on aphid

272 fitness was detected, and whether the direction of the effect was positive or negative.

273 Studies which reported non-significant results were categorised as null response.

274 Data were deemed as significant based on the statistical reporting in each study

275 (significance was determined by $p=<0.05$ ). For studies measuring the responses of

276 several aphid species (such as Foote et al., 2017), the results of the statistical

277 analysis at the drought treatment level, not the species $\mathrm{x}$ drought interaction level,

278 were used to determine whether the observation was significant amongst all aphid 279 species.

\section{Aphid response analysis: Meta-analysis procedure}

Two meta-analyses were carried out using the two datasets described above: 1) an analysis using the "global" dataset pooled across aphid species and host plant giving one pooled effect size per study (55 data points); 2) an analysis using the "expanded" dataset which was pooled at the aphid species and host plant levels and separated by aphid fitness parameter, giving multiple pooled effect sizes per study (93 data points).

For the first meta-analysis ("global" dataset), data were analysed using a linear mixed effects model fitted with restricted maximum likelihood distribution. The difference between the plant-aphid systems was examined in a subsequent model by incorporating this factor a fixed term. For the second meta-analysis ("expanded" dataset), 'study' was incorporated as a random term to account for multiple data points in some studies and to avoid potential pseudo-replication. Data were analysed in a similar way to the method above: briefly, a random linear mixed effects model fitted with restricted maximum likelihood distribution was used to examine differences between aphid tribes, aphid host range, and the plant-aphid system in three models. In a further model, the responses of the different aphid fitness parameters were tested.

\section{Plant response analysis: Meta-analysis procedure}

32,12 , and ten studies also reported the effect of drought on plant vigour, plant tissue nutrient concentration, and tissue defensive compound concentrations, 
302 with restricted maximum likelihood distribution. Data were analysed in an individual

303 model for each plant response.

Results

\section{Aphid fitness is reduced under drought}

306 The vote counting procedure (Fig. 2) indicated that aphid fitness is reduced when 307 exposed to drought stressed plants. Analysis of the pooled data indicated that aphid 308 fitness is generally reduced under drought $\left(Q_{M}=26.71 ; p=<0.001\right.$; Supplementary 309 Fig. 3), average Hedges' $g=-0.57 ; 95 \%$ confidence interval $\left(\mathrm{Cl}_{95}\right)= \pm 0.31$. 310 Subsequent comparisons were carried out after separating the data into the plant311 aphid system. Pooled data were significantly heterogeneous, indicated by Cochran's $312 \mathrm{Q}\left(\mathrm{Q}_{E}=404.34 ; \mathrm{df}=54 ; \mathrm{p}=<0.001\right)$. Further comparison indicated that aphid fitness 313 was broadly reduced under drought across plant-aphid systems $\left(Q_{M}=25.81 ; p=\right.$ $314<0.001$; Fig. 3). However, due to low replication for some groups, a comprehensive 315 comparative analysis was not possible. No trends over publication time were observed for pooled aphid responses (Supplementary Fig. 8).

To analyse the effect of drought on aphid fitness in relation to aphid tribe and aphid host range, and to identify any differences between fitness parameters, a second dataset comprising 93 data observations over the 55 studies was compiled (the "expanded" dataset). Meta-analysis of this expanded dataset indicated that aphid fitness was reduced under drought $\left(Q_{M}=18.03 ; p=0.003\right.$; Fig. 4 insert). Most aphid fitness parameters examined, especially parameters intrinsically associated with aphid abundance (fecundity and population size) and development, were negatively affected by drought $\left(Q_{M}=91.88 ; p=<0.001\right.$; Fig. 4). Drought decreased aphid fitness to a similar extent across the different aphid tribes $\left(Q_{M}=19.45 ; p=0.002\right)$ : Aphidini $\left(\mathrm{g}=-0.55 ; \mathrm{Cl}_{95}= \pm 0.38\right)$, Macrosiphini $\left(\mathrm{g}=-0.85 ; \mathrm{Cl}_{95}= \pm 0.37\right)$, and Other $(\mathrm{g}$ $\left.=-0.32 ; \mathrm{Cl}_{95}= \pm 1.18\right)$. Fitness decreases were similar for aphids with contrasting host plant ranges $\left(Q_{M}=14.13 ; p=0.001\right)$ : specialist $\left(g=-0.67 ; C_{95}= \pm 0.32\right)$, generalist $\left(\mathrm{g}=-0.90 ; \mathrm{Cl}_{95}= \pm 0.54\right)$. 
332 Meta-analysis of the pooled plant responses to drought (Supplementary Fig. 5 - 7)

333 indicated that exposure to drought has an overall negative effect on plant vigour $\left(Q_{M}\right.$

$334=35.97 ; \mathrm{p}=<0.001$; Fig. 5) and, on average, results in more chemically-defended 335 plant tissues $\left(Q_{M}=46.37 ; p=<0.001\right.$; Fig. 5). However, tissue $N$ and amino acid 336 concentrations did not increase consistently $\left(Q_{M}=4.92 ; p=0.178\right.$; Fig. 5). The 337 consistency of the relation between drought effects on aphid fitness, plant vigour and 338 plant chemical defence, but not plant nutritional quality, is shown in Supplementary 339 Fig. 9. No trends over publication time were observed for any plant responses 340 (Supplementary Fig. 8).

Discussion

This study provides the first comprehensive assessment of aphid and host plant responses to drought stress, analysed in terms of aphid fitness and plant vigour, nutritional quality, and chemical defence. The meta-analysis supported our prediction that drought reduces aphid fitness, and this effect was linked most consistently with reduced plant vigour rather than altered tissue nutrient concentrations, although increased chemical defence of plant tissues might also play a role. Our study includes data extracted from 81 (qualitative assessment) and 55 studies (quantitative assessment), including 42 papers for quantitative assessment published between 2003 - 2020 that were not included in an earlier meta-analysis across different insect feeding guilds (Huberty \& Denno, 2004). Our findings, therefore, represent a significant advance in knowledge on the effects of drought on sap-feeding insects with a novel focus on drought effects on aphids as an ecologically important insect group.

\section{Plant vigour could explain drought effects on aphid fitness}

The primary finding that aphid fitness is reduced when feeding on drought stressed hosts confirms the findings of Huberty \& Denno (2004) for sap-feeding insects. Our study goes further, however, by providing evidence for the underlying mechanisms. We show that decreased aphid fitness is most frequently associated with the negative effects of drought on plant growth (vigour), with some evidence that plant tissue concentrations of defensive chemicals or signalling compounds play an important role. It should be noted that, out of the studies included in our metaanalysis, over half measured plant vigour (32 studies) while only around one-fifth 
364 measured tissue concentrations of defensive compounds ( $n=10)$. Most of these 365 studies showed a strong association between decreased aphid performance, 366 reduced plant vigour and increased tissue concentrations of plant defensive 367 compounds, but no clear association with tissue nutrient concentrations. This finding 368 is consistent with our prediction and is supported by a large body of literature 369 reporting elevated chemical defence and decreased plant growth and vigour under 370 drought (Templer et al., 2017; Beetge \& Krüger 2019; Xie et al., 2020). As less 371 vigorous plants have a higher concentration of biochemical defences, drought stress 372 could lead to increased aphid exposure to plant defensive compounds, leading to 373 reduced fitness due to feeding deterrence and decreased phloem ingestion.

374 A secondary aim of this meta-analysis was to examine the consistency of drought 375 effects across aphid groups and aphid-plant systems to identify factors which could 376 explain differential effects (Oswald \& Brewer, 1997; Hale et al., 2003). All aphid tribes assessed showed decreased aphid fitness in response to drought and a similar response was observed when aphids were categorised as specialists or generalists. However, there was an overrepresentation of the Aphidini and Macrosiphini tribes (45 out of the 55 studies) because many empirical studies focus on agriculturally or ecologically important aphid species, which are widely represented in these two tribes (Kim \& Lee 2008; Choi et al., 2018). This limits the extent to which differences between tribes can be detected and further experimental work would be needed to confirm consistent drought responses across aphid groups. For example, it could be hypothesised that aphid species which actively remobilise plant nutrients (e.g. D. noxia; see Sandström, Telang \& Moran, 2000) are less affected by drought than species that are unable to maintain a sufficient supply of plant nutrients. Similarly, species that can sequester plant defensive chemicals (e.g. Brevicoryne brassicae (Linnaeus); see Kazana et al. 2007) might better tolerate increased concentrations of toxic plant chemicals in response to drought.

391 Similarly, aphid fitness was generally reduced on drought stressed plants across all 392 plant groups assessed, but there was an overrepresentation of two plant groups 393 (Cereal and Tree groups), which prevents firm conclusions. Nonetheless, these 394 findings confirm that the effect of drought on herbivorous insects is primarily 
395 mediated by general changes in plant physiology, as indicated by Cornelissen et al.

396 (2008).

\section{The role of host plant defence in aphid responses to drought}

398 Although based on a relatively small number of studies, our analysis indicated that 399 plant chemical defence is elevated under drought, and this correlates with reduced 400 aphid fitness. Several studies highlight the effects of anti-herbivore plant resistance 401 strategies on aphid fitness under benign conditions (Guerrieri \& Digilio, 2008; 402 Greenslade et al., 2016), but few studies have examined whether host plant 403 resistance against aphids is modified under climate stress. From the 55 studies 404 assessed here, only five included observations of aphid responses on both 405 susceptible and (partially)-resistant plant types (Oswald \& Brewer, 1997; Björkman 406 2000; Dardeau et al., 2015; Verdugo, Sauge, Lacroze, Francis \& Ramirez, 2015; 407 Guo et al., 2016) with one further study examining aphid responses on resistant 408 plants only (Ramirez \& Verdugo, 2009). Additionally, three studies compared aphid 409 responses on drought tolerant and drought susceptible host plants (De Farias, 410 Hopper, Leclant, 1995; Rousselin et al., 2018; Quandahor, Lin, Gou, Coulter \& Liu, $4112019)$ and only one study examined the interactive effects of aphid resistance and 412 drought tolerance (Grettenberger \& Tooker, 2016). Such a low level of 413 representation means that the interactive effect between plant resistance and 414 drought could not be investigated empirically using meta-analysis. Of these studies, 415 four report similar findings: aphid fitness is reduced on both susceptible and resistant 416 plant hosts (Oswald \& Brewer; Björkman; Dardeau et al.; Guo et al.), with a smaller 417 reduction in fitness on the resistant host plant than on the susceptible host plant 418 (Oswald \& Brewer; Dardeau et al.). These findings indicate that while aphid fitness is reduced on resistant plants under benign conditions, under drought it decreases to similarly low values on susceptible and resistant plants. This highlights a significant knowledge gap in our understanding of how plant resistance traits are affected by

422 environmental stress, which is becoming increasingly important for successful pest 423 management in changing climatic conditions.

424 To stimulate further research into this potentially important interaction between plant 425 resistance, herbivore success, and climatic conditions, we propose a simplified 426 conceptual model to predict how aphids will respond to drought in relation to altered 
427 host-plant resistance, termed the Plant Resistance Hypothesis (Fig. 6). This expands

428 upon previous conceptual models, the plant stress hypothesis and plant vigour

429 hypothesis, which do not consider the potential differences in plant susceptibility to 430 herbivorous insect pests. This new model suggests that under benign conditions the 431 basal level of aphid fitness will differ between the susceptible (high aphid fitness) and 432 resistant (moderate-to-low aphid fitness) plant types, as will the level of plant 433 defence: susceptible (low level of defence) vs. resistant (high level of defence).

434 Drought is likely to cause a reduction in plant vigour and decreased plant palatability 435 for the aphid, characterised by elevated concentrations of plant defensive 436 compounds (Inbar, Doostdar \& Mayer, 2001; Ozturk et al., 2002), leading to 437 differential changes in the chemical defence of susceptible (from low to high 438 concentration) and resistant (continually high concentration) plants. Differential levels 439 of basal aphid fitness between the two plant types leads to differences in the extent 440 to which aphid fitness is affected by drought depending on whether the host is a 441 susceptible (from high fitness to low fitness) or resistant (from intermediate fitness to 442 low fitness) plant type.

\section{Drought-induced reduction in aphid fitness could destabilise aphid-trophic} interactions

Aphids represent an important group of herbivorous insects from both an economic perspective, in relation to agricultural crop protection, and an ecological perspective, regarding the diverse community of higher trophic groups they support. The central finding of our meta-analysis is that exposure to drought-stressed hosts is detrimental to aphid fitness, although the extent of this effect is likely affected by host plant suitability as an aphid food source. Consequently, higher incidences of drought will have a detrimental effect on the terrestrial trophic networks that are supported by aphids: aphids are widespread in vegetation systems globally, are abundant consumers of primary production in many ecosystems, and provide a food source for many trophic groups (Gilbert 2005; Messelink et al., 2012; Roubinet et al., 2018). Our findings, largely based on aphid species in the Aphidini and Macrosiphini tribes, indicate that individual and population level measures of aphid fitness are affected negatively by drought, suggesting that drought will have cascading consequences for

458 host plant consumption by aphids and the abundance of other trophic groups. If 
460 could reduce the availability of aphid hosts for parasites and pathogens (Nguyen,

461 Michaud \& Cloutier, 2007; Ahmed, Liu \& Simon, 2012; Aslam, et al., 2013) and

462 decrease food availability for aphid predators (Wade, Karley, Johnson \& Hartley, 463 2017). Similarly, many aphids are tended by ants for their honeydew secretions 464 (Stadler et al., 2003). These ants provide protective services to plants by deterring 465 herbivory by other insect pests (Offenberg, Nielsen, Maclntosh, Havanon \& 466 Aksomkoae, 2004; Rosumek et al., 2009). While reduced aphid fitness might 467 decrease plant consumption, it could also compromise the protective services 468 delivered by ants: lower aphid abundance, or decreased honeydew quantity or 469 quality, could decrease ant attendance (see Stadler, Kindlmann, Šmilauer \& Fiedler, 470 2003), thereby exacerbating the detrimental effects of drought by increasing plant 471 exposure to additional biotic stressors.

472 Ecological networks often exist in stable equilibria (McQuaid \& Britton, 2015; Landi, 473 Minoarivelo, Brännström, Hui \& Dieckmann., 2018), with a change in the abundance 474 of one species or functional group leading to perturbations in abundance and 475 diversity across the network (McQuaid \& Britton, 2015). A drought-induced reduction 476 in aphid fitness might decrease abundance, mass, or quality of aphids available to 477 support other trophic levels, with potential to destabilise population equilibria; a 478 recent modelling study illustrated that the destabilising effects of drought on aphid479 parasitoid interactions lead to altered insect population cycles (Preedy, Chaplain, 480 Leybourne, Marion \& Karley, 2020). A key finding of this meta-analysis was that 481 plant resistance to aphids may influence the extent to which aphids are negatively 482 affected by drought. The negative consequences of plant resistance for aphids 483 generally include decreased fecundity (Greenslade et al., 2016; Leybourne et al., 484 2019) which could reduce aphid abundance for aphid natural enemies. This could 485 have further consequences for aphid/insect distributions in regions that are 486 experiencing more frequent drought events. Analysing the effects on aphid-natural 487 enemy interactions of drought, and its interactions with other determinants of host 488 suitability, is therefore an important avenue for future research to understand the 489 impacts on the composition and function of ecological networks and species 490 distributions (e.g. Rodríguez-Castaneda, 2013). This will improve our understanding 491 of how drought and plant suitability characteristics might contribute to recent reports 492 of increased rates of species loss and population declines (Saunders, Janes \& 
493 O'Hanlon, 2020; Leather, 2018). Our conceptual model of the anticipated effects of

494 drought on aphid fitness in relation to plant resistance, plant vigour, and chemical

495 defence provides a basis for stimulating future research on insect-plant interactions 496 under a changing climate.

\section{References}

498 Agele S., Ofuya T. \& James P. (2006). Effects of watering regimes on aphid infestation and 499 performance of selected varieties of cowpea (Vigna unguiculata L. Walp) in a humid rainforest zone 500 of Nigeria. Crop Protection, 25, 73-78.

501 Ahmed S., Liu D. \& Simon J.-C. (2012). Impact of water-defecit stress on tritrophic interactions in a 502 wheat-aphid-parasitoid system. PLOS ONE, 12, e0186599.

503 Aslam T., Johnson S. \& Karley A. (2013). Plant-mediated effects of drought on aphid population 504 structure and parasitoid attack. Journal of Applied Entomology, 137, pp. 136-145.

505 Banfield-Zanin J. \& Leather S. (2015). Reproduction of an arboreal aphid pest, Elatobium abietinum, 506 is altered under drought stress. Journal of Applied Entomology, 139, pp. 302-313.

507 Beetge L. \& Krüger K. (2019). Drought and heat waves associated with climate change affect 508 performance of the potato aphid Macrosiphum euphorbiae. Scientific Reports, 9, e3645.

509 Blackman R. \& Eastop V. (2000). Aphids on the world's crops - an identification and information 510 guide. New York: John Wiley and Sons, Ltd.

511 Blenkinsop S. \& Fowler H. (2007). Changes in European drought characteristics projected by the 512 PRUDENCE regional climate models. International Journal of Climatology, 27, pp. 1595-1610.

513 Björkman C. (2000). Interactive effects of host resistance and drought stress on the performance of 514 a gall-making aphid living on Norway spruce. Oecologia, 123, pp. 223-231

515 Choi H., Shin S., Jung S., Clarke DJ. \& Lee S. (2018). Molecular phylogeny of Macrosiphini (Hemiptera: 516 Aphididae): An evolutionary hypothesis for the Pterocomma-group habitat adaptation. Molecular 517 Phylogenetics and Evolution, 121, pp. 12-22.

518 Cooper H., Hedges L. \& Valenting, J. (2019). The handbook of research synthesis and meta-analysis: 519 The Russel Sage Foundation.

520 Cornelissen T., Fernandes G. \& Vasconcellos-Neto J. (2008). Size does matter: variation in herbivory 521 between and within plants and the plant vigour hypothesis. Oikos, 117, pp. 1121-1130.

522 Dai P., Liu D. \& Shi X. (2015). Impacts of water deficiency on life history of Sitobion avenae clones

523 from semi-arid and moist areas. Journal of Economic Entomology, 108, pp. 2250-2258.

524 Dardeau F., Berthier A., Feinard-Duranceau M., Brignolas F., Laurans F., Lieutier F. \& Sallé A. (2015).

525 Tree genotype modulates the effects of water deficit on a plant-manipulating aphid. Forest Ecology 526 and Management, 353, pp. 118-125.

527 De Farias A., Hopper K. \& Leclant F. (1995). Damage symptoms and abundance of Diuraphis noxia 528 (Homoptera, Aphididae) for 4 wheat cultivars at 3 irrigation levels. Journal of Economic Entomology, 529 88, pp. 169-174.

530 Foote N., Davis TS., Crowder DW., Bosque-Pérez NA. \& Eigenbrode SD. (2017). Plant water stress 531 affects interactions between an invasive and a naturalized aphid species on cereal crops.

532 Environmental Entomology, 46, pp. 609-616. 
533 Gilbert F. (2005). Syrphid aphidophagus predators in a food-web context. European Journal of

534 Entomology, 102, pp. 325-333.

535 Greenslade AFC., Ward JL., Martin JL., Corol DI., Clark SJ., Smart LE. \& Aradottir GI. (2016). Triticum

536 monococcum lines with distinct metaboloic phenotypes and phloem-based partial resistance to the

537 bird cherry-oat aphid Rhopalosiphum padi. Annals of Applied Biology, 168, pp. 435-449.

538 Grettenberger I. \& Tooker J. (2016). Inter-varietal interactions among plants in genotypically diverse 539 mixtures tend to decrease herbivore performance. Oecologia, 182, pp. 189-202.

540 Guerrieri E. \& Digilio M. (2008). Aphid-plant interactions: a review. Journal of Plant Interactions, 3, 541 pp. 223-232.

542 Guo H., Sun Y., Peng X., Wang Q., Harris M. \& Ge F. (2016). Up-regulation of abscisic acid signaling 543 pathway facilitates aphid xylem absorption and osmoregulation under drought stress. Journal of 544 Experimental Botany, 67, pp. 681-693.

545 Hagen KS. \& van den Bosch R. (1968). Impact of pathogens, parasities, and predators on aphids.

546 Annual Review of Entomology, 13, pp. 325-384.

547 Hale B., Bale JS., Pritchard J., Masters GJ. \& Bworn VK. (2003). Effects of host plant drought stress on 548 the performance of the bird cherry-oat aphid, Rhopalosiphum padi (L.): a mechanistic analysis.

549 Ecological Entomology, 28, pp. 666-677.

550 Hatier, J-HB., Faville MJ., Hickey MJ., Koolaard JP., Schmidt B-LC. \& Jones CS. (2014). Plant vigour at 551 establishment and following defoliation are both associated with responses to drought in perennial 552 ryegrass (Lolium perenne L.). Journal of Experiemntal Botany, 65, pp 5823-5834.

553 Higgins J. (2008). Commentary: Heterogeneity in meta-analysis should be expected and 554 appropriately quantified. International Journal of Epidemiology, 37, pp. 1158-1160.

555 Huberty A. \& Denno R. (2004). Plant water stress and its consequences for herbivorous insects: a 556 new synthesis. Ecology, 85, pp. 1383-1398.

557 Inbar M., Doostdar H. \& Mayer, R. (2001). Suitability of stressed and vigorous plants to various insect 558 herbivores. Oikos, 94, pp. 228-235.

559 Johnson S., Staley J., McLeod F. \& Hartley S. (2011). Plant-mediated effects of soil invertebrates and 560 summer drought on above-ground multitrophic interactions. Journal of Ecology, 99, pp. 57-65.

561 Kazana E., Pope TW., Tibbles L., Bridges M., Pickett JA., Bones AM., ... Rossiter JT. (2007). The

562 cabbage aphid: a walking mustard oil bomb. Proceedings of the Royal Society B, 274, pp. 2271-2277.

563 Kim H. \& Lee S. (2008). A molecular phylogeny of the tribe Aphidini (Insecta: Hemiptera: Aphididae)

564 based on the mitochondrial tRNA/COII, 12S/16S and the nuclear EF1 $\alpha$ genes. Systematic

565 Entomology, 33, pp. 711-721.

566 Koricheva J. \& Larsson S. (1998). Insect performance on experimentally stressed woody plants: A

567 meta-analysis. Annual Review of Entomology, 43, pp. 195-216

568 Landi P., Minoarivelo HO., Brännström Å., Hui C. \& Dieckmann U. (2018). Complexity and stability of 569 ecological neworks: a review of the theory. Population Ecology, 60, pp. 319-345.

570 Leather S.R. (2018) "Ecological Armageddon" - more evidence for the drastic decline in insect 571 numbers. Annals of Applied Biology, 172, pp. 1-3.

572 Lefort M-C., Wratten SD., Cusumano A., Varennes Y-D. \& Boyer S. (2017). Disentangling higher 573 trophic level interactions in the cabbage aphid food web using high-throughput DNA sequencing.

574 Metabarcoding and Metagenomics, 1, e13709. 
575 Leybourne DJ., Valentine TA., Robertson J., Pérez-Fernández E., Main AM., Karley AJ. \& Bos JIB.

576 (2019). Defence gene expression and phloem quality contribute to mesophyll and phloem resistance 577 to aphids in wild barley. Journal of Experimental Botany, 70, pp 4011-4026

578 Luo D., Wan X., Liu J. \& Tong T. (2018). Optimally estimating the sample mean from the sample size, 579 median, mid-range, and/or mid-quartile range. Statistical Methods in Medical Research, 27, pp.

$580 \quad 1785-7805$.

581 McQuaid C. \& Britton N. (2015). Parasite species richness and its effect on persistence in food webs. 582 Journal of Theoretical Biology, 364, pp. 377-382.

583 Messelink G., Sabelis MW. \& Janssen A. (2012). Generalist predators, food web complexities and 584 biological pest control in greenhouse crops. In: M. Larramendy \& S. Soloneski, eds. Integrated pest 585 management and pest control - current and future tactics: Intechopen, pp. 191-214.

586 Mewis I., Khan MAM., Glawischnig E., Schreiner M. \& Ulrichs C. (2012). Water stress and aphid 587 feeding differentially influence metabolite composition in Arabidopsis thaliana (L.). PLOS ONE, 7, 588 e48661.

589 Mody K., Eichenberger D. \& Dorn S. (2009). Stress magnitude matters: different intensities of pulsed 590 water stress produce non-monotonic resistance responses of host plants to insect herbivores.

591 Ecological Entomology, 34, pp. 133-143.

592 Moher D., Liberati A., Tetzlaff J. \& Altman DG. (2009). Preferred reporting items for systematic 593 reviews and meta-analyses: the PRISMA statement. BMJ, 339, e2535

594 Nakagawa S., Noble WAN., Senior AM. \& Lagisz M. (2017). Meta-evaluation of meta-analysis: ten 595 appraisal questions for biologists. BMC Biology, 15, e18

596 Nguyen T., Michaud D. \& Cloutier C. (2007). Proteomic profiling of aphid Macrosiphum euphorbiae 597 responses to host-plant-mediated stress induced by defoliation and water defecit. Journal of Insect 598 Physiology, 53, pp. 601-611.

599 Offenberg J., Nielsen MG., Maclntosh DJ., Havanon S. \& Aksomkoae S. (2004). Evidence that insect 600 herbivores are deterred by ant pheromones. Proceedings of the Royal Society B, 271, pp. S433-S435.

601 Orwin R. (1983). A fail-safe $\mathrm{n}$ for effect size in meta-analysis. Journal of Educational Statistics, 8, pp. 602 157-159.

603 Osakabe Y., Osakabe K., Shinozaki K. \& Trans L.-S. (2014). Response of plants to water stress. 604 Frontiers in plant Science, 5, p. 86.

605 Oswald C. \& Brewer M. (1997). Aphid-barley interactions mediated by water stress and barley 606 resistance to Russian wheat aphid (Homoptera: Aphididae). Environmental Entomology, 26, pp. 591607602.

608 Ozturk Z., Talamé V., Deyholos M., Michalowski CB., Galbraith DW., Gozukirmizi N., ... Bohnert HJ. 609 (2002). Monitoring large-scale changes in transcript abundance in drought- and salt-stressed barley. 610 Plant Molecular Biology, 48, pp. 551-573.

611 Pons X. \& Tatchel G. (1995). Drought stress and cereal aphid performance.. Annals of Applied 612 Biology, 126, pp. 19-31.

613 Preedy K., Chaplain MA., Leybourne DJ., Marion G. \& Karley AJ. (2020). Learning-induced switching 614 costs in a parasitoid can maintain diversity of host aphid phenotypes although biocontrol is 615 destabilized under abiotic stress. Journal of Animal Ecology, 89, pp. 1216-1229.

616 Quandahor P., Lin C., Gou Y., Coulter J. \& Liu C. (2019). Leaf morphological and biochemical 617 responses of three potato (Solanum tuberosum L.) cultivars to drought stress and aphid (Myzus 618 persicae Sulzer) infestation. Insects 10, 435 
619 Ramirez C. \& Verdugo J. (2009). Water availability affects tolerance and resistance to aphids but not 620 the trade-off between the two. Ecological Research, 24, pp. 881-888.

621 Rodríguez-Castañeda G. (2013). The world and its shades of green: a meta-analysis on trophic 622 cascades across temperature and precipitation gradients. Global Ecology and Biogeography, 22, pp. $623 \quad 118-130$.

624 Romo C. \& Tylianakis J. (2013). Elevated temperature and drought interact to reduce parasitoid 625 effectiveness in suppressing hosts. PLOS ONE, 8, p. e58136.

626 Rosumek F., Silveira FAO., Never F de S., Barbosa NP de U., Diniz L., Oki Y., ... Cornelissen T. (2009).

627 Ants on plants: a meta-analysis of the role of ants as plant biotic defenses. Oecologia, 160, pp. 537-

628549.

629 Roubinet E., Jonsson T., Malsher G., Staudacher K., Traugott M., Ekbom B. \& Jonsson M. (2018). High 630 redundancy as well as complementary prey choice characterise generalist predator food webs in 631 agroecosystems. Scientific Reports, 8, p. 8054.

632 Rousselin A., Bevacqua D., Vercambre C., Sauge M-H., Lescourret F. \& Jordan M-O. (2018). Rosy 633 apple aphid abundance on apple is shaped by vegetative growth and water status. Crop Protection, 634 105, pp. 1-9.

635 Sandström J., Telang A. \& Moran N. (2000). Nutritional enhancement of host plants by aphids - a 636 comparison of three aphid species on grasses. Journal of Insect Physiology, 46, pp. 33-40.

637 Santos A., Belo-Pereira M., Fraga H. \& Pinto J. (2016). Understanding climate change projections for 638 precipitation over western Europe with a weather typing approach. Journal of Geophysical Research: 639 Atmospheres, 121, pp. 1170-1189.

640 Saunders ME., Janes JK., \& O'Hanlon JC. (2020). Moving on from the insect apocalypse narrative: 641 engaging with evidence-based insect conservation. BioScience. 70, pp. 80-89

642 Stadler B., Kindlmann P., Šmilauer P. \& Fiedler K. (2003). A comparative analysis of morphological 643 and ecological characters of European aphids and lycaenids in relation to ant attendance. Oecologia, 644 135, pp. 422-430.

645 Staudacher K., Jonsson M. \& Traugott M. (2016). Diagnostic PCR assays to unravel food web 646 interactions in cereal crops with a focus on biological control of aphids. Journal of pest science, 89, 647 pp. 281-293.

648 Staley JT., Mortimer SR., Masters GJ., Morecroft MD., Brown ME. \& Taylor D. (2006) Drought stress 649 differentially affects leaf-mining species. Ecological Entomology, 31, pp. 460-469

650 Teixeira N., Valim J., Oliveira M. \& Campos W. (2020). Combined effects of soil silicon and drought 651 stress on host plant chemical and ultrastructural quality for leaf-chewing and sap-sucking insects. 652 Journal of Agronomy and Crop Science, 206, pp. 187-201.

653 Templer SE., Ammon A., Pscheidt D., Ciobotea O., Schuy C., McCollum C., ... Voll LM. (2017). 654 Metabolite profiling of barley flag leaves under drought and combined heat and drought stress 655 reveals metabolic QTLs for metabolites associated with antioxidant defense. Journal of Experimental 656 Botany, 68, pp. 1697-1713.

657 Traugott M., Bell JR., Broad GR., Powell W., van Veen FJF., Vollhardt IMG. \& Symondson WOC. 658 (2008). Endoparasitism in cereal aphids: molecular analysis of a whole parasitoid community. 659 Molecular Ecology, 17, pp. 3928-3938.

660 Van Emden H. \& Harrington R. (2017). Aphids as crop pests. Wallingford: Cabi Publishing. 
bioRxiv preprint doi: https://doi.org/10.1101/2020.06.24.168112; this version posted December 10,2020 . The copyright holder for this preprint (which was not certified by peer review) is the author/funder, who has granted bioRxiv a license to display the preprint in perpetuity. It is made available under aCC-BY-NC 4.0 International license.

21

661 Verdugo J., Sauge M.-H., Lacroze J.-P. Francis, F. \& Ramirez, C. (2015). Drought-stress and plant 662 resistance affect herbivore performance and proteome: the case of the green peach aphid Myzus 663 persicae (Hemiptera: Aphididae). Physiological Entomology, 40, pp. 265-276.

664 Wade R., Karley A., Johnson S. \& Hartley S. (2017). Impact of predicted precipitation scenarios on 665 multitrophic interactions. Functional Ecology, 31, pp. 1647-1658.

666 Wan X., Wang W. Liu J., \& Tong T. (2014). Estimating the sample mean and standard deviation from 667 the sample size, median, range and/or interquartile range. BMC Medical Research Methodology, 14, 668 p. 135.

669 White T. (1969). An index to measure weather-induced stress of trees associated with outbreaks of 670 psyllids in Australia. Ecology, 50, pp. 905-909.

671 Wickham H. (2016). ggplot2: elegant graphics for data analysis. 2: Springer International Publishing.

672 Xie H., Shi J., Shi F., Xu H., He K. \& Wang Z. (2020). Aphid fecundity and defenses in wheat exposed to 673 a combination of heat and drought stress. Journal of Experimental Botany, 71, pp. 2713-2722.

674 Xing G., Zhang J., Liu J., Zhang X., Wang G. \& Wang Y. (2003). Impacts of atmospheric $\mathrm{CO}_{2}$ 675 concentrations and soil water on the population dynamics, fecundity and development of the bird 676 cherry-oat aphid Rhopalosiphum padi. Phytoparasitica, 31, pp. 499-514.

677 Zeppel M., Wilks J. \& Lewis J. (2014). Impacts of extreme precipitation and seasonal changes in 678 precipitation on plants. Biogeosciences, 11, pp. 3083-3093.

679

\section{Data accessibility statement}

681 Data will be uploaded to the Dryad data repository upon acceptance of the 682 manuscript for publication. 
bioRxiv preprint doi: https://doi.org/10.1101/2020.06.24.168112; this version posted December 10, 2020. The copyright holder for this preprint (which was not certified by peer review) is the author/funder, who has granted bioRxiv a license to display the preprint in perpetuity. It is made available under aCC-BY-NC 4.0 International license.

22

\section{Tables}

685 Table 1: information on the aphid species included in the meta-analysis, the agricultural and 686 ecological importance of each species, and the number of data points present in the 687 "Expanded" dataset.

\begin{tabular}{|c|c|c|c|c|}
\hline Aphid species & Common name & $\begin{array}{l}\text { Aphid tribe / } \\
\text { Specialism } \\
\text { (generalist or } \\
\text { specialist) }\end{array}$ & $\begin{array}{l}\text { Agricultural and ecological } \\
\text { importance }\end{array}$ & $\begin{array}{c}\text { Number of data } \\
\text { points: "Expanded" } \\
\text { dataset and study } \\
\text { from which data were } \\
\text { extracted }\end{array}$ \\
\hline $\begin{array}{l}\text { Aphis glycines } \\
\text { Matsumura }\end{array}$ & Soybean aphid & Aphidini / Specialist & $\begin{array}{l}\text { Significant pest of soybean across North } \\
\text { America and Asia }\end{array}$ & 1 datapoint from study 31 \\
\hline A. Pomi DeGeer & Apple aphid & Aphidini / Specialist & $\begin{array}{l}\text { Significant pest of apple trees, specifically } \\
\text { on nursery stock. Colonies can be } \\
\text { attended by ants }\end{array}$ & 1 datapoint from study 29 \\
\hline $\begin{array}{l}\text { Brevicoryne brassicae } \\
\text { (Linnaeus) }\end{array}$ & Cabbage aphid & $\begin{array}{l}\text { Macrosiphini / } \\
\text { Generalist }\end{array}$ & $\begin{array}{l}\text { Wax-covered aphid. Widely distributed } \\
\text { throughout Europe, major pest of } \\
\text { Brassicaceae }\end{array}$ & $\begin{array}{l}8 \text { datapoints from studies } \\
23,37,47,48.49\end{array}$ \\
\hline $\begin{array}{l}\text { Cinara costata } \\
\text { (Zetterstedt) }\end{array}$ & Mealy spruce aphid & $\begin{array}{l}\text { Eulachnini (Other) / } \\
\text { Specialist }\end{array}$ & $\begin{array}{l}\text { Wax-covered aphid. Can cause damage to } \\
\text { spruce trees. Unlike other Cinara spp. } C \text {. } \\
\text { costata is not readily attended by ants. }\end{array}$ & 1 datapoint from study 24 \\
\hline C. pinea (Mordvilko) & Large pine aphid & $\begin{array}{l}\text { Eulachnini (Other) / } \\
\text { Specialist }\end{array}$ & $\begin{array}{l}\text { Forestry pest of Scotts pine and other } \\
\text { Pinus spp. Often found on young pine } \\
\text { trees. }\end{array}$ & 1 datapoint from 32 \\
\hline $\begin{array}{l}\text { Dysaphis plantaginea } \\
\text { (Passerini) }\end{array}$ & Rosy apple aphid & $\begin{array}{l}\text { Macrosiphini / } \\
\text { Specialist }\end{array}$ & $\begin{array}{l}\text { Widely distributed across temperate } \\
\text { regions and a significant pest of apples. } \\
\text { Colonies develop in galls and are attended } \\
\text { by ants. }\end{array}$ & 1 datapoint from study 41 \\
\hline $\begin{array}{l}\text { Elatobium abietinum } \\
\text { (Walker) }\end{array}$ & Green spruce aphid & $\begin{array}{l}\text { Macrosiphini / } \\
\text { Specialist }\end{array}$ & $\begin{array}{l}\text { Distributed across Europe and North } \\
\text { America. Can cause economic and } \\
\text { environmental damage by causing needle } \\
\text { defoliation on Spruce trees. }\end{array}$ & $\begin{array}{l}6 \text { datapoints from studies } 2 \text {, } \\
4,5,6\end{array}$ \\
\hline $\begin{array}{l}\text { Lipaphis erysimi } \\
\text { (Kaltenbach) }\end{array}$ & Wild crucifer aphid & $\begin{array}{l}\text { Macrosiphini / } \\
\text { Specialist }\end{array}$ & Can feed on various Brassicaceae crops. & 1 datapoint form study 23 \\
\hline
\end{tabular}


bioRxiv preprint doi: $h$ ttps://doi.org/10.1101/2020.06.24.168112; this version posted December 10,2020 . The copyright holder for this preprint (which was not certified by peer review) is the author/funder, who has granted bioRxiv a license to display the preprint in perpetuity. It is made available under aCC-BY-NC 4.0 International license.

\section{3}

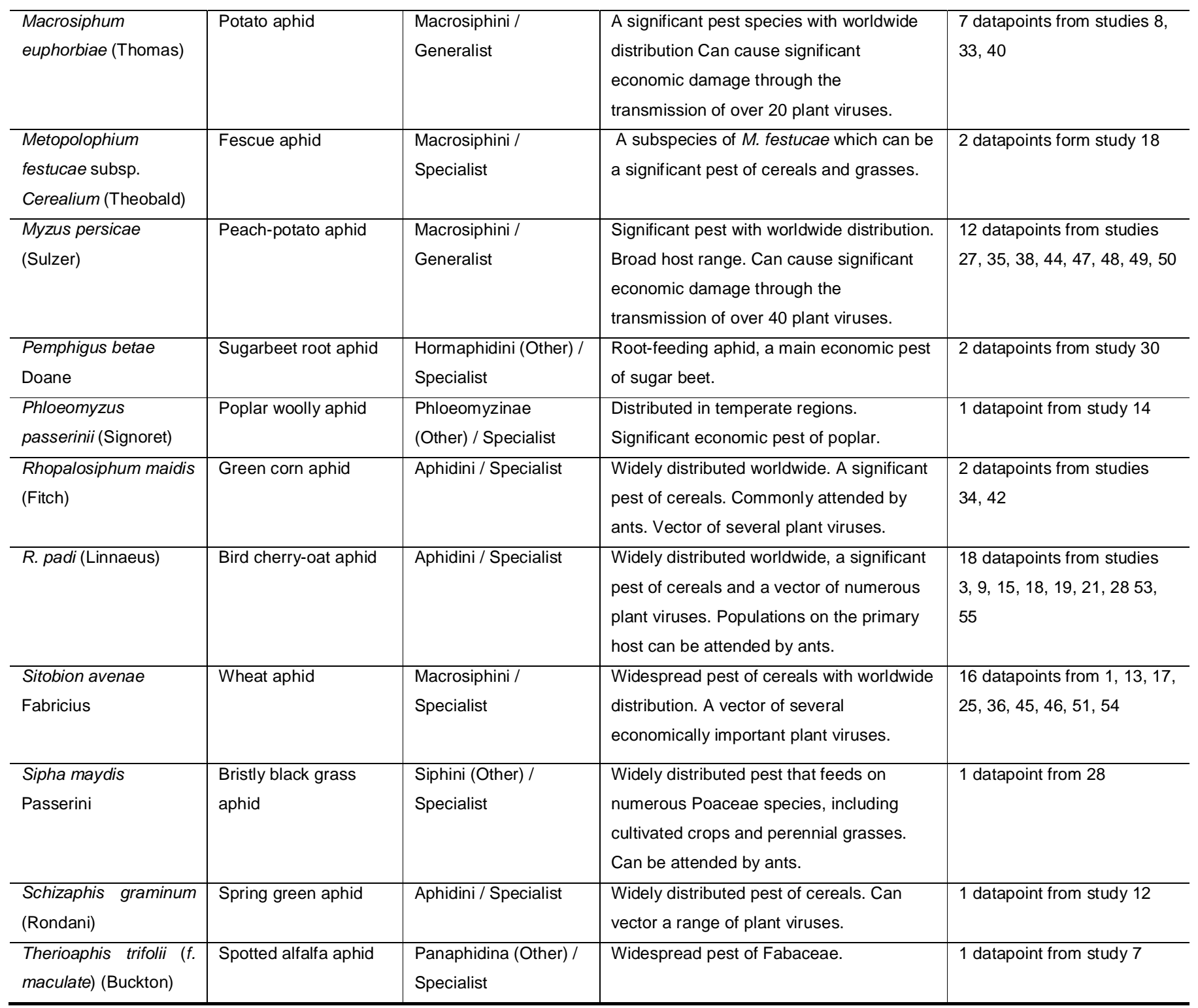

$688 \square$ Full study references are contained in Appendix 2

689 
bioRxiv preprint doi: https://doi.org/10.1101/2020.06.24.168112; this version posted December 10,2020 . The copyright holder for this preprint (which was not certified by peer review) is the author/funder, who has granted bioRxiv a license to display the preprint in perpetuity. It is made available under aCC-BY-NC 4.0 International license.

24

\section{Figures and Figure Legends}

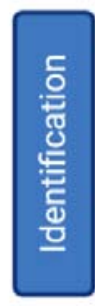

Studies identified through Web of

Science $(n=190)$

Studies identified through Scopus

$(n=197)$

\section{Studies extracted from \\ Huberty \& Denno (2004) $(n=16)$}

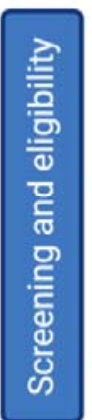

Studies after duplicates removed $(n=263)$

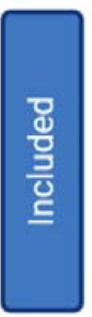

Studies included in qualitative assessment

(vote-counting) $(n=81)$

Studies included in quantitative assessment (meta-analysis) $(n=55)$

691

Fig. 1: PRISMA diagram

693 
bioRxiv preprint doi: https://doi.org/10.1101/2020.06.24.168112; this version posted December 10, 2020. The copyright holder for this preprint (which was not certified by peer review) is the author/funder, who has granted bioRxiv a license to display the preprint in perpetuity. It is made available under aCC-BY-NC 4.0 International license.

25

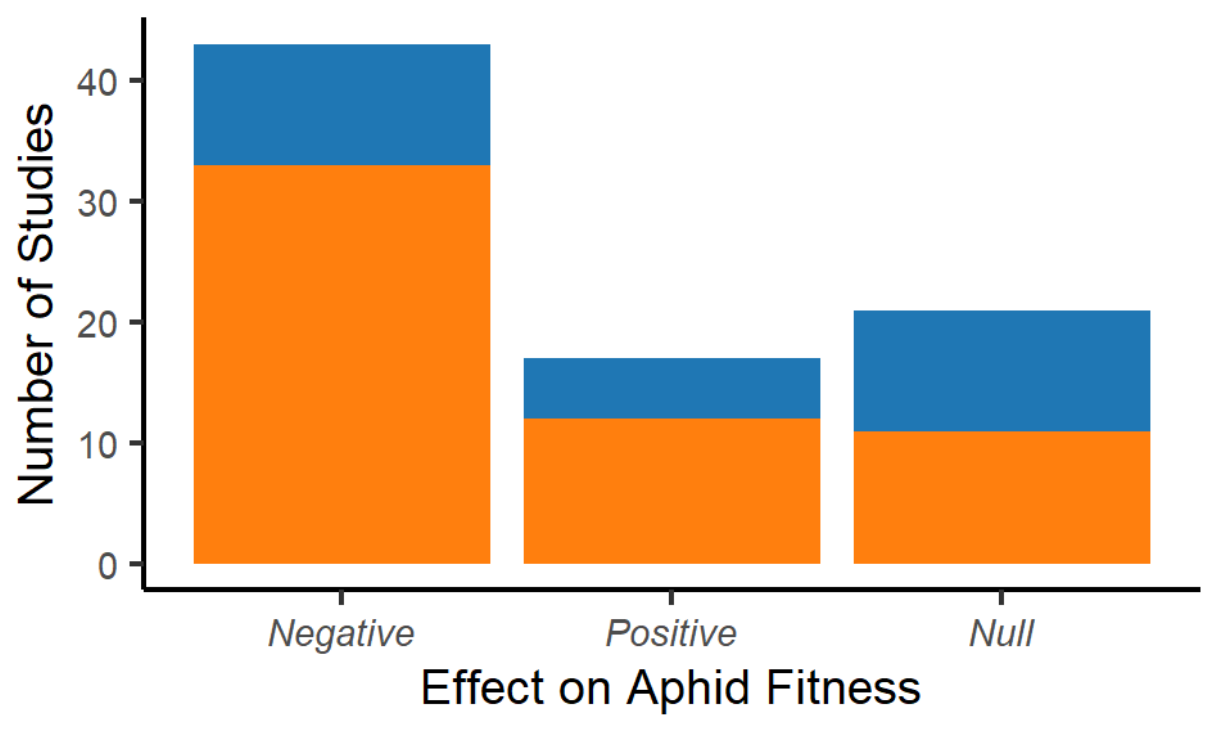

695

696 Fig. 2: The number of studies reporting negative, positive, or null effects of drought stress on aphid 697 fitness. Bars are coloured to indicate the proportion of studies in each category that were included 698 in the full meta-analysis (Orange) vs those in the complete dataset (Blue). 
bioRxiv preprint doi: https://doi.org/10.1101/2020.06.24.168112; this version posted December 10,2020 . The copyright holder for this preprint (which was not certified by peer review) is the author/funder, who has granted bioRxiv a license to display the preprint in perpetuity. It is made available under aCC-BY-NC 4.0 International license.

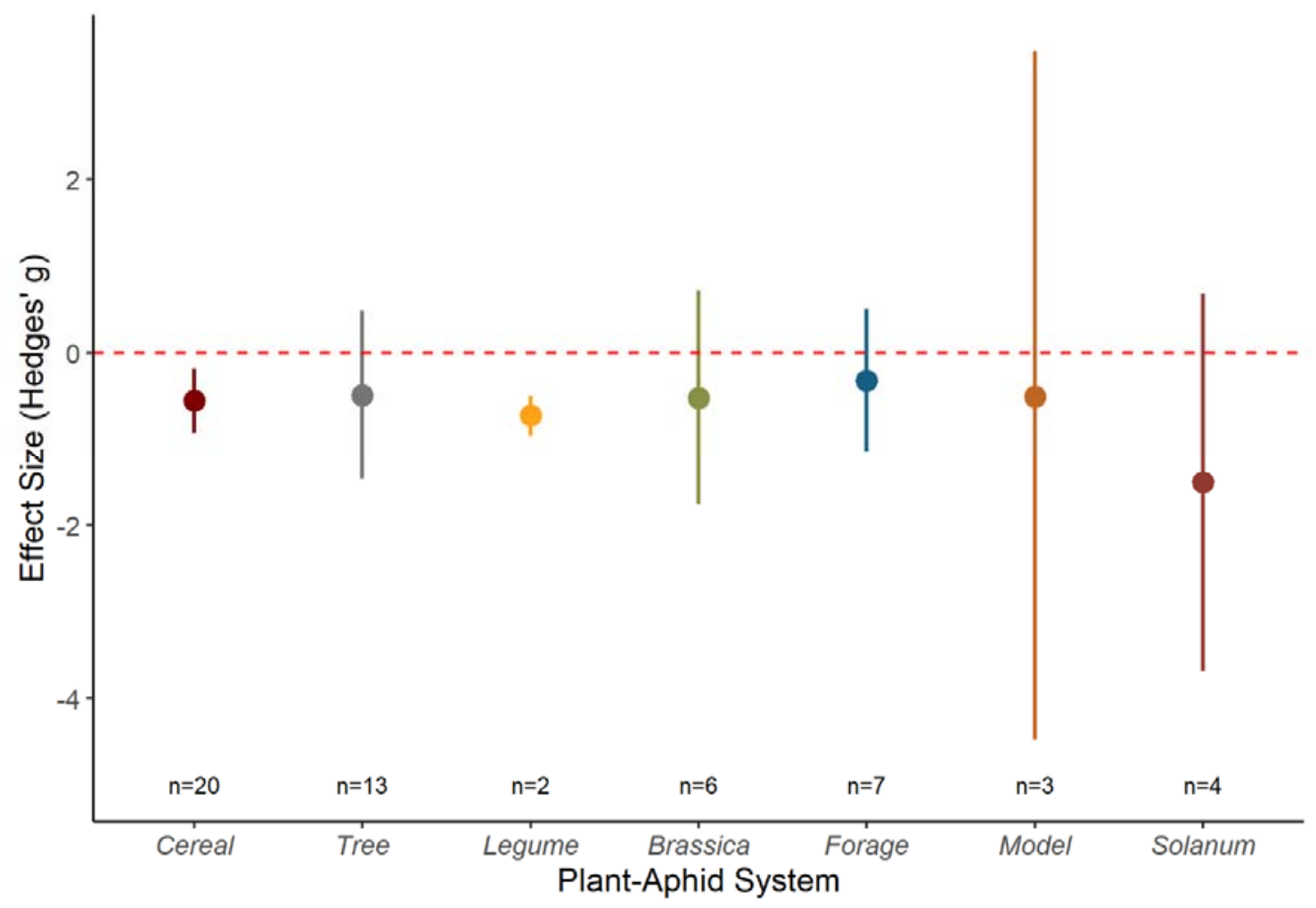

701 Fig. 3: Effect of the plant-aphid system on overall aphid responses to drought stress conditions using the "global" dataset where response variables were pooled to produce one effect size per study. Graph displays the mean effect size (Hedges' g) and the 95\% 704 confidence intervals for the different plant-aphid systems identified from the extracted data. 705 Red dashed line represents zero effect size. 
bioRxiv preprint doi: https://doi.org/10.1101/2020.06.24.168112; this version posted December 10,2020 . The copyright holder for this preprint (which was not certified by peer review) is the author/funder, who has granted bioRxiv a license to display the preprint in perpetuity. It is made available under aCC-BY-NC 4.0 International license.

27

707

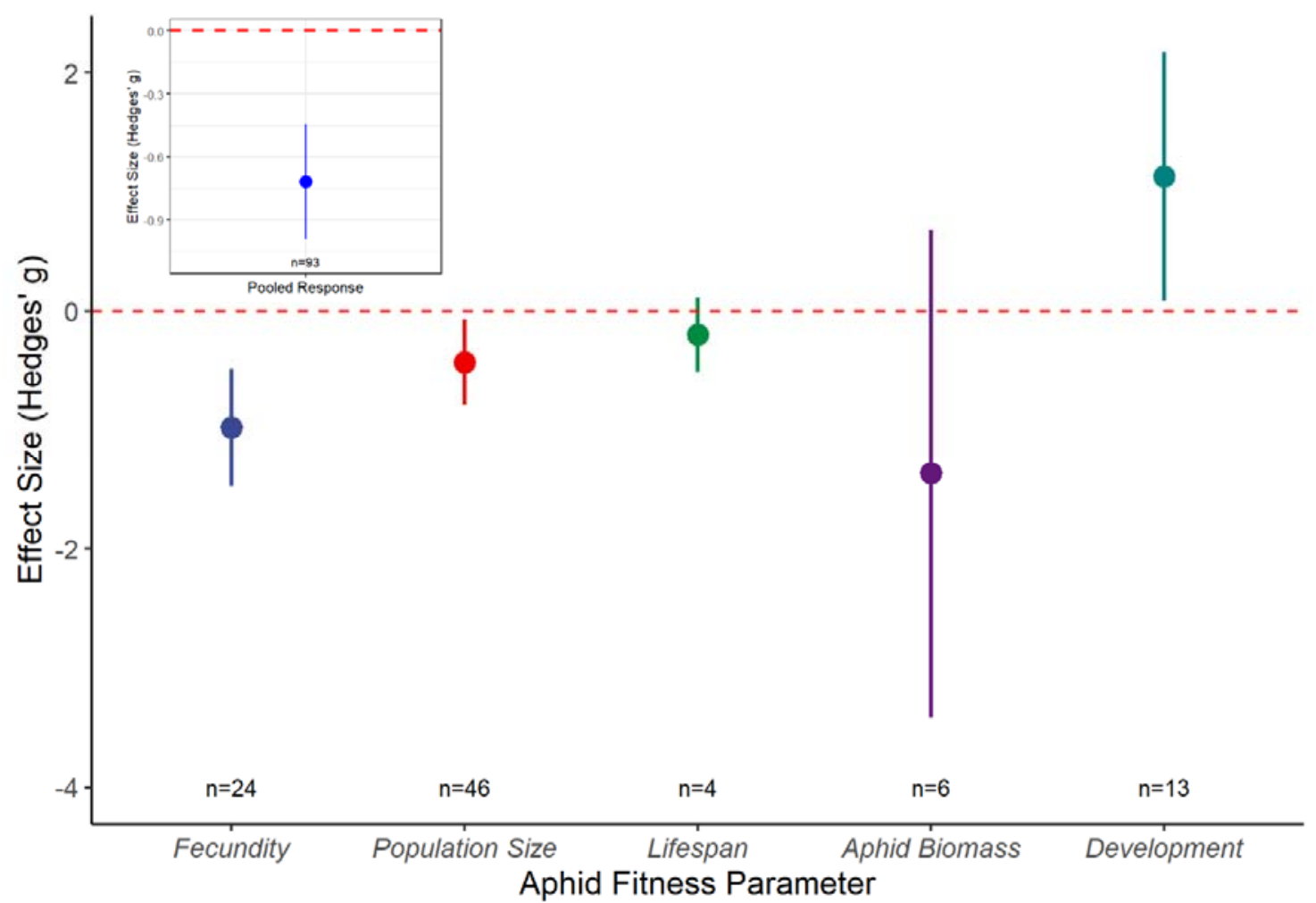

708 Fig. 4: Responses of aphids to drought stress using the "expanded" dataset which included

709 an effect size per response variable and for each aphid species measured in each study.

710 Main graph displays the mean effect size (Hedges' g) and the 95\% confidence intervals for

711 the different plant-aphid systems identified from the extracted data. Insert displays the mean

712 effect size (Hedges' g) and the 95\% confidence intervals for the combined data. Red dashed

713 line represents zero effect size. 
bioRxiv preprint doi: https://doi.org/10.1101/2020.06.24.168112; this version posted December 10,2020 . The copyright holder for this preprint (which was not certified by peer review) is the author/funder, who has granted bioRxiv a license to display the preprint in perpetuity. It is made available under aCC-BY-NC 4.0 International license.

\section{8}

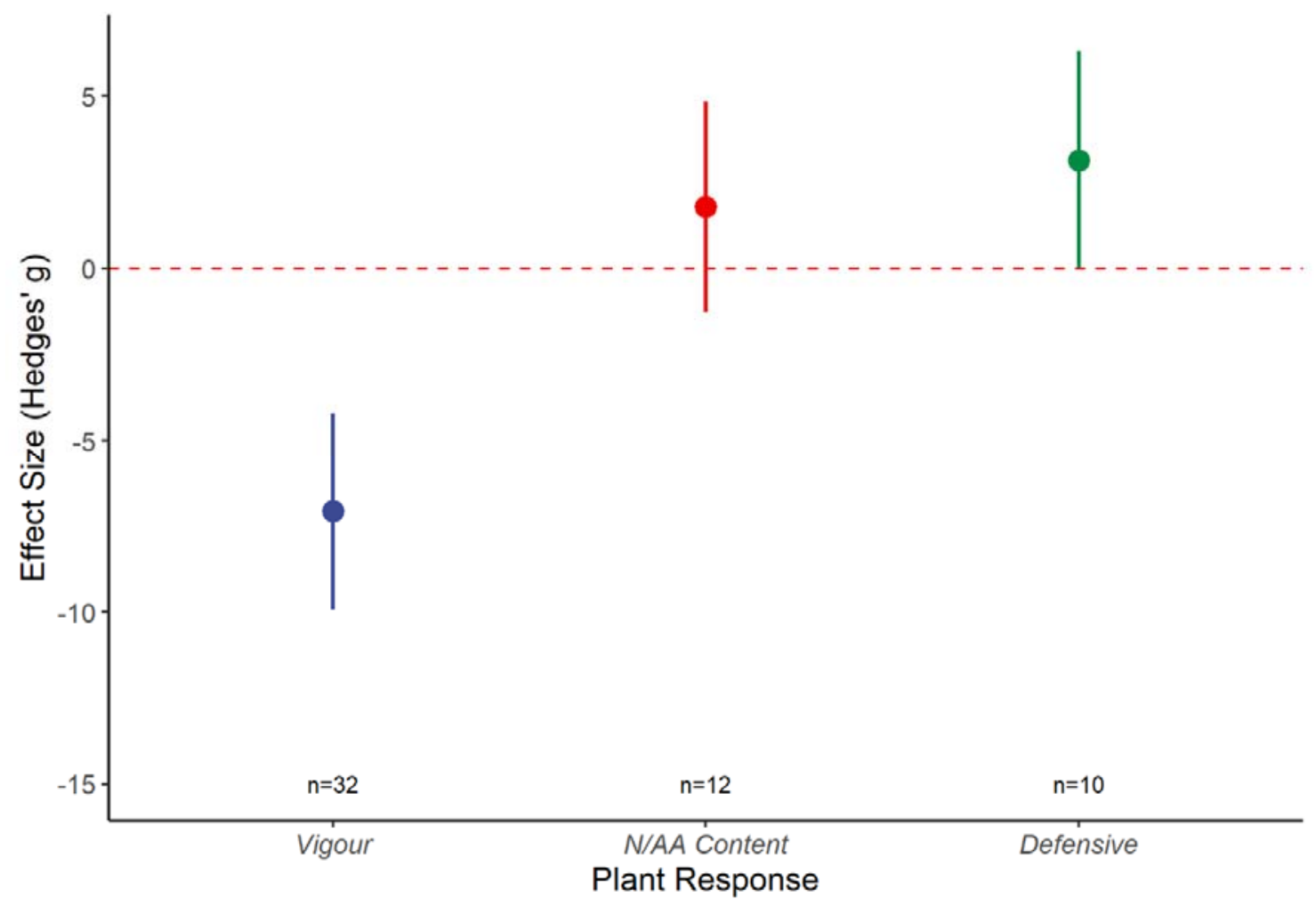

716 Fig. 5: The effect of drought stress on plant vigour using the "plant" dataset where measures 717 of plant vigour (vigour), $\mathrm{N}$ or amino acid (AA) concentration (N/AA Content), or tissue 718 concentrations of defensive compounds (Defensive) were reported. Graph displays the 719 mean effect size (Hedges' g) and the 95\% confidence intervals for the different plant-aphid 720 systems identified from the extracted data. Red dashed line represents zero effect size. 
bioRxiv preprint doi: https://doi.org/10.1101/2020.06.24.168112; this version posted December 10,2020 . The copyright holder for this preprint (which was not certified by peer review) is the author/funder, who has granted bioRxiv a license to display the preprint in perpetuity. It is made available under aCC-BY-NC 4.0 International license.

29

722

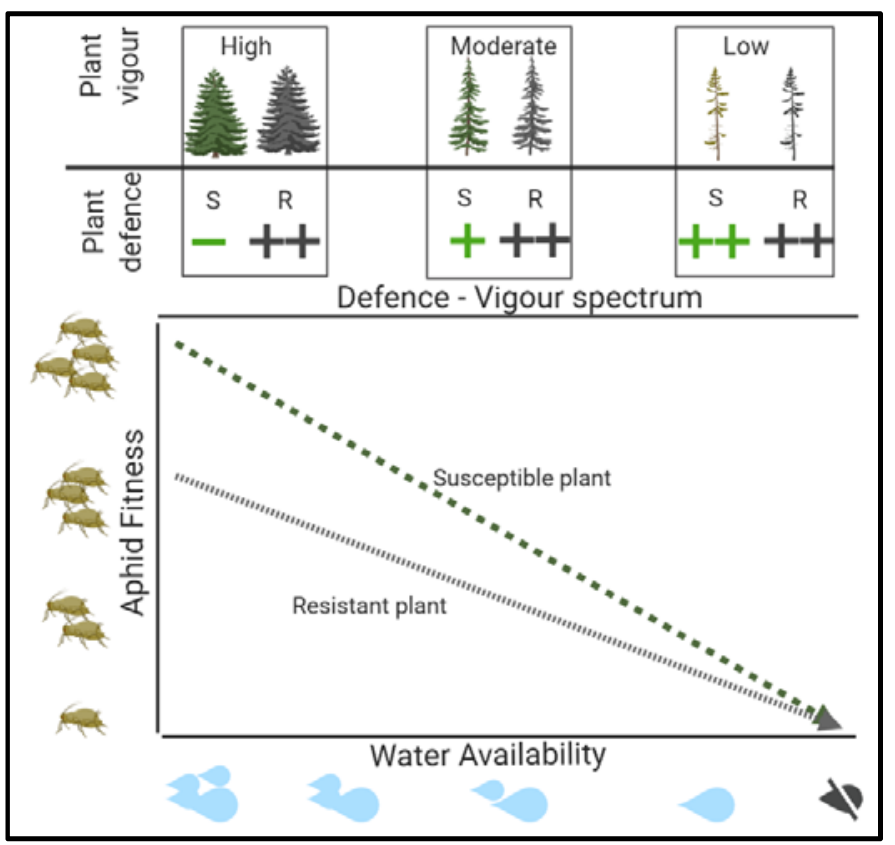

732 Fig. 6: Conceptual representation of the Plant Resistance Hypothesis (PRH). As water

733 availability decreases plant defence increases and plant vigour declines, leading to reduced

734 aphid fitness. Basal levels of aphid fitness under conditions of ample water availability differ

735 between the susceptible ( $S$, green line) and the resistant ( $R$, grey line) plant types. Under

736 drought, aphid fitness is reduced on both plant types, however the extent of this reduction is

737 greater for the susceptible plant (high to low fitness) than the resistant plant (intermediate to

738 low fitness). This image made in BioRender (c) - biorender.com 
740

741

742

743

744

745

746

747

748

749

750

751

752

753

754

755

756

757

758

759

760

761

762

763

764

765

766

767

768

769

770

771

772

773

774

775

776

777

778

779

780

781

782

783

784

785

786

787

\section{Appendices}

Appendix 1: References for the 25 studies which were included in the "vote-counting" analysis but excluded from the full meta-analysis

1. Agele SO., Ofuya TI. \& James PO. (2006). Effects of watering regimes on aphid infestation and performance of selected varieties of cowpea (Vigna unguiculata L. Walp) in a humid rainforest zone of Nigeria. Crop Protection 25, 73-78.

2. Banfield-Zanin JA. \& Leather SR. (2014). Frequency and intensity of drought stress alters the population size and dynamics of Elatobium abietinum on Sitka spruce. Annals of Applied Biology 165, 260-269.

3. Björkman C. (2000). Interactive effects of host resistance and drought stress on the performance of a gall-making aphid living on Norway spruce. Oecologia 123, 223231

4. Braun S. \& Flückiger W. (1984). Increased population of the aphid Aphis pomi at a motorway. Part 2-The effect of drought and deicing salt. Environmental Pollution. Series A, Ecological and Biological, 36, 261-270

5. DeVries NEL. \& Manglitz GR. (1982). Spotted alfalfa aphid (Therioaphis maculata (Buckton)) (Homoptera: Aphididae): water stress, amino acid content and plant resistance. Journal of the Kansas Entomological Society 55, 57-64

6. Forbes AE., Harvey CT. \& Tilmon KJ. (2005). Variation in the responses of spotted alfalfa aphids, Therioaphis maculata Buckton (Homoptera: Aphididae) and pea aphids, Acythosiphon pisum Harris (Homoptera: Aphididae) to drought conditions in alfalfa (Medicago sativa L., Fabaceae). Journal of the Kansas Entomological Society, 78, 387-389

7. Gange AC. \& Brown VK. (1989). Effects of root herbivory by an insect on a foliarfeeding species, mediated through changes in the host plant. Oecologia, 81, 38-42.

8. Karley AJ., Emslie-Smith M. \& Bennett AE. (2017). Potato aphid Macrosiphum euphorbiae performance is determined by aphid genotype and not mycorrhizal fungi or water availability. Insect Science, 24, 1015 - 1024.

9. Kennedy JS., Lamb KP. \& Booth CO. (1958). Responses of Aphis fabae Scop. to water shortage in host plants in pots. Entomologia Experimentalis et Applicata, 1, 274-290.

10. Khan MAM., Ulrichs C. \& Mewis I. (2010). Influence of water stress on the glucosinolate profile of Brassica oleracea var. italica and the performance of Brevicoryne brassicae and Myzus persicae. Entomologia Experimentalis et Applicata, 137, 229-236.

11. Khan MAM., Ulrichs C. \& Mewis I. (2011a). Drought stress - impact on glucosinolate profile and performance of phloem feeding cruciferous insects. In: Hale C, ed. Xxviii International Horticultural Congress on Science and Horticulture for People, 111-117.

12. Khan MAM., Ulrichs C. \& Mewis I. (2011b). Effect of water stress and aphid herbivory on flavonoids in broccoli (Brassica oleracea var. italica Plenck). Journal of Applied Botany and Food Quality-Angewandte Botanik, 84, 178-182.

13. Latimer JG \& Oetting RD. (1994). Brushing reduces thrips and aphid populations on some greenhouse-grown vegetable transplants. Hortscience, 29, 1279-1281.

14. McMurtry J. (1962). Resistance of alfalfa to spotted alfalfa aphid in relation to environmental factors. Hilgardia 32, 501-539. DOI:10.3733/hilg.v32n12p501

15. Michels GJ Jr. \& Undersander DJ. (1986). Temporal and spatial distribution of the Greenbug (Homoptera: Aphididae) on sorghum in relation to water stress. Journal of Economic Entomology 79, 1221-1225. 
16. Miles P., Aspinall D. \& Rosenberg L. (1982). Performance of the cabbage aphid, Brevicoryne brassicae (L.), on water-stressed rape plants, in relation to changes in their chemical composition. Australian Journal of Zoology, 30, 337-346.

17. Pons X. \& Tatchell GM. (1995). Drought stress and cereal aphid performance. Annals of Applied Biology, 126, 19-31.

18. Romo CM. \& Tylianakis JM. (2013). Elevated temperature and drought interact to reduce parasitoid effectiveness in suppressing hosts. PLOS ONE, 8.

19. Salas ML. \& Corcuera LJ. (1991). Effect of environment on gramine content in barely leaves and susceptibility to the aphid Schizaphis graminum. Phytochemistry, 30, 3237-3240.

20. Service PM. \& Lenski RE. (1982). Aphid genotypes, plant phenotypes, and genetic diversity: a demographic analysis of experimental data. Evolution, 36, 1276-1282

21. Teixeira N., Valim J., Oliveira M. \& Campos W. (2020). Combining effects of soil silicon and drought stress on host plant chemical and ultrastructural quality for leafchewing and sap-sucking insects. Journal of Agronomy and Crop Science, 206 187201

22. Volpe V., Chitarra W., Cascone P., Volpe MG., Bartolini P., Moneti G., ... Balestrini R. (2018). The association with two different arbuscular mycorrhizal fungi differently affects water stress tolerance in tomato. Frontiers in Plant Science, 9.

23. Wearing $\mathrm{CH}$. (1967). Studies on the relations of insect and host plant: ii. effects of water stress in host plants on the fecundity of Myzus persicae (Sulz.) and Brevicoryne brassicae (L.). Nature, 213, 1052-1053.

24. Wearing CH. (1972). Responses of Myzus persicae and Brevicoryne brassicae to leaf age and water stress in brussels sprouts grown in pots. Entomologia Experimentalis et Applicata, 15, 61-80.

25. Wearing CH. \& Van Emden HF. (1967). Studies on the relations of insect and host plant: i. effects of water stress in host plants on infestation by Aphis fabae Scop, Myzus persicae (Sulz.) and Brevicoryne brassicae (L.). Nature, 213, 1051-1052. 
817

818

819

820

821

822

823

824

825

826

827

828

829

830

831

832

833

834

835

836

837

838

839

840

841

842

843

844

845

846

847

848

849

850

851

852

853

854

855

856

857

858

859

860

861

862

863

864

Appendix 2: References for the 55 studies which were included in the full meta-analysis. $\square$ indicates which studies contained more than one data point when split into the "expanded responses" dataset. * Indicates which studies reported on plant physiological, defensive, or nutritional responses for inclusion in the plant meta-analysis

1. Ahmed SS., Liu D. \& Simon J-C. (2017). Impact of water-deficit stress on tritrophic interactions in a wheat-aphid-parasitoid system. PLOS ONE, 12, e0186599.

2. Archer TL., Bynum ED., Onken AB. \& Wendt CW. (1995). Influence of water and nitrogen fertilizer on biology of the Russian wheat aphid (Homoptera: Aphididae) on wheat. Crop Protection, 14, 165-169. *

3. Aslam TJ., Johnson SN. \& Karley AJ. (2013). Plant-mediated effects of drought on aphid population structure and parasitoid attack. Journal of Applied Entomology, 137, 136-145. *

4. Banfield-Zanin JA. \& Leather SR. (2015A). Drought intensity and frequency have contrasting effects on development time and survival of the green spruce aphid. Agricultural and Forest Entomology, 17, 309-316. $\square$

5. Banfield-Zanin JA. \& Leather SR. (2015B). Reproduction of an arboreal aphid pest, Elatobium abietinum, is altered under drought stress. Journal of Applied Entomology, 139, 302-313.

6. Banfield-Zanin JA \& Leather SR. (2015C). Season and drought stress mediate growth and weight of the green spruce aphid on Sitka spruce. Agricultural and Forest Entomology, 17, 48-56.

7. Barton BT. \& Ives AR. (2014). Species interactions and a chain of indirect effects driven by reduced precipitation. Ecology, 95, 486-494.

8. Beetge L. \& Kruger K. (2019). Drought and heat waves associated with climate change affect performance of the potato aphid Macrosiphum euphorbiae. Scientific Reports, 9. $\square^{*}$

9. Bultman TL. \& Bell GD. (2003). Interaction between fungal endophytes and environmental stressors influences plant resistance to insects. Oikos, 103, 182-190. *

10. Björkman C .(2000). Interactive effects of host resistance and drought stress on the performance of a gall-making aphid living on Norway spruce. Oecologia, 123, 223231 *

11. Björkman C. (1998). Opposite, linear and non-linear effects of plant stress on a galling aphid. Scandinavian Journal of Forest Research, 13, 177-183 *

12. Cabrera HM., Argandona VH., Zuniga GE. \& Corcuera LJ. (1995). Effect of infestation by aphids on the water status of barley and insect development. Phytochemistry, 40, 1083-1088. *

13. Dai P., Liu D. \& Shi X. (2015). Impacts of Water Deficiency on Life History of Sitobion avenae Clones from Semi-arid and Moist Areas. Journal of Economic Entomology, 108, 2250-2258.

14. Dardeau F., Berthier A., Feinard-Duranceau M., Brignolas F., Laurans F., Lieutier F. \& Salle A. (2015). Tree genotype modulates the effects of water deficit on a plantmanipulating aphid. Forest Ecology and Management, 353, 118-125. *

15. Davis TS., Bosque-Pérez NA., Foote NE., Magney T. \& Eigenbrode SD. (2015). Environmentally dependent host-pathogen and vector-pathogen interactions in the Barley yellow dwarf virus pathosystem. Journal of Applied Ecology, 52, 1392-1401. *

16. De Farias AMI., Hopper KR. \& Leclant F. (1995). Damage symptoms and abundance of Diuraphis noxia (homoptera, aphididae) for 4 wheat cultivars at 3 irrigation levels. Journal of Economic Entomology, 88, 169-174. 
17. Fereres A., Gutierrez C., Del Estal P. \& Castañera P. (1988). Impact of the English Grain Aphid, Sitobion avenae (F.) (Homoptera: Aphididae), on the Yield of Wheat Plants Subjected to Water Deficits. Environmental Entomology, 17, 596-602. *

18. Foote NE., Davis TS., Crowder DW., Bosque-Perez NA. \& Eigenbrode SD. (2017). Plant Water Stress Affects Interactions Between an Invasive and a Naturalized Aphid Species on Cereal Crops. Environmental Entomology, 46, 609-616. $\square$ *

19. Grettenberger IM. \& Tooker JF. (2016). Inter-varietal interactions among plants in genotypically diverse mixtures tend to decrease herbivore performance. Oecologia, 182, 189-202. *

20. Guo H., Sun Y., Peng X., Wang Q., Harris M. \& Ge F. (2016). Up-regulation of abscisic acid signaling pathway facilitates aphid xylem absorption and osmoregulation under drought stress. Journal of experimental botany, 67, 681-693. *

21. Hale BK., Bale JS., Pritchard J., Masters GJ. \& Brown VK. (2003). Effects of host plant drought stress on the performance of the bird cherry-oat aphid, Rhopalosiphum padi (L.): a mechanistic analysis. Ecological Entomology, 28, 666-677. $\square^{*}$

22. Johnson SN., Staley JT., McLeod FAL. \& Hartley SE. (2011). Plant-mediated effects of soil invertebrates and summer drought on above-ground multitrophic interactions. Journal of Ecology, 99, 57-65. *

23. King C., Jacob HS. \& Berlandier F. (2006). The influence of water deficiency on the relationship between canola (Brassica napus L.), and two aphid species (Hemiptera : Aphididae), Lipaphis erysimi (Kaltenbach) and Brevicoryne brassicae (L.). Australian Journal of Agricultural Research, 57, 439-445. $\square^{*}$

24. Larsson S. \& Bjorkman C. (1993). Performance of chewing and phloem-feeding insects on stressed trees. Scandinavian Journal of Forest Research, 8, 550-559.

25. Liu D., Dai P., Li S., Ahmed SS., Shang Z. \& Shi X. (2018). Life-history responses of insects to water-deficit stress: a case study with the aphid Sitobion avenae. BMC Ecology 18.

26. McVean RIK. \& Dixon AFG. (2001). The effect of plant drought-stress on populations of the pea aphid Acyrthosiphon pisum. Ecological Entomology, 26, 440-443. *

27. Mewis I., Khan MAM., Glawischnig E., Schreiner M. \& Ulrichs C. (2012). Water Stress and Aphid Feeding Differentially Influence Metabolite Composition in Arabidopsis thaliana (L.). PLoS ONE, 7, e48661. $\square^{*}$

28. Miranda IM., Omacini M. \& Chaneton EJ. (2011). Environmental context of endophyte symbioses: Interacting effects of water stress and insect herbivory. International Journal of Plant Sciences, 172, 499-508. $\square^{*}$

29. Mody K,. Eichenberger D. \& Dorn S. (2009). Stress magnitude matters: different intensities of pulsed water stress produce non-monotonic resistance responses of host plants to insect herbivores. Ecological Entomology, 34, 133-143. *

30. Moran NA. \& Whitham TG. (1988). Population Fluctuations in Complex Life Cycles: An Example from Pemphigus Aphids. Ecology, 69, 1214-1218.

31. Nachappa P., Culkin CT., Saya PM., Han J. \& Nalam VJ. (2016). Water Stress Modulates Soybean Aphid Performance, Feeding Behavior, and Virus Transmission in Soybean. Frontiers in Plant Science, 7, 552. *

32. Neuvonen S., Routio I. \& Haukioja E. (1992). Combined effects of simulated acid rain and aphid infestation on the growth of Scots pine (Pinus sylvestris) seedlings. Annales Botanici Fennici, 29, 101-106

33. Nguyen TTA., Michaud D. \& Cloutier C. (2007). Proteomic profiling of aphid Macrosiphum euphorbiae responses to host-plant-mediated stress induced by defoliation and water deficit. Journal of Insect Physiology, 53, 601-611. $\square$ 
34. Oswald CJ. \& Brewer MJ. (1997). Aphid-barley interactions mediated by water stress and barley resistance to Russian wheat aphid (Homoptera: Aphididae). Environmental Entomology, 26, 591-602. $\square^{*}$

35. Pineda A., Pangesti N., Soler R., van Dam NM., van Loon JJA. \& Dicke M. (2016). Negative impact of drought stress on a generalist leaf chewer and a phloem feeder is associated with, but not explained by an increase in herbivore-induced indole glucosinolates. Environmental and Experimental Botany, 123, 88-97. *

36. Pons C., Voß A-C., Schweiger R. \& Müller C. (2020). Effects of drought and mycorrhiza on wheat and aphid infestation. Ecology and Evolution, 10, 10481-10491 *

37. Prill N., Bullock JM., van Dam NM, \& Leimu R. 2014. Loss of heterosis and familydependent inbreeding depression in plant performance and resistance against multiple herbivores under drought stress. Journal of Ecology, 102, 1497-1505. *

38. Quandahor P., Lin C., Gou Y., Coulter J. \& Liu C. (2019). Leaf morphological and biochemical responses of three potato (Solanum tuberosum L.) cultivars to drought stress and aphid (Myzus persicae Sulzer) infestation. Insects, 10, $435 \square^{*}$

39. Ramirez CC. \& Verdugo JA. (2009). Water availability affects tolerance and resistance to aphids but not the trade-off between the two. Ecological Research, 24, 881-888.

40. Rivelli A., Trotta V., Toma I., Fanti P. \& Battaglia D. (2013). Relation between plant water status and Macrosiphum euphorbiae (Hemiptera: Aphididae) population dynamics on three cultivars of tomato. European Journal of Entomology, 110, 617625. *

41. Rousselin A., Bevacqua D., Vercambre G., Sauge MH., Lescourret F. \& Jordan MO. (2018). Rosy apple aphid abundance on apple is shaped by vegetative growth and water status. Crop Protection, 105, 1-9. *

42. Rudgers JA. \& Swafford AL. (2009). Benefits of a fungal endophyte in Elymus virginicus decline under drought stress. Basic and Applied Ecology, 10, 43-51. *

43. Ryalls JMW., Moore BD., Riegler M. \& Johnson SN. (2016). Above-Below ground Herbivore Interactions in Mixed Plant Communities Are Influenced by Altered Precipitation Patterns. Frontiers in Plant Science, 7. *

44. Simpson KLS., Jackson GE. \& Grace J. 2012. The response of aphids to plant water stress - the case of Myzus persicae and Brassica oleracea var. capitata. Entomologia Experimentalis et Applicata, 142, 191-202. $\square^{*}$

45. Smyrnioudis IN., Harrington R., Karis N. \& Clark SJ. (2000). The effect of drought stress and temperature on spread of barley yellow dwarf virus (BYDV). Agricultural and Forest Entomology, 2, 161-166

46. Tamburini G., van Gils S., Kos M., van der Putten W. \& Marini L. (2018). Drought and soil fertility modify fertilization effects on aphid performance in wheat. Basic and Applied Ecology, 30, 23-31. $\square^{*}$

47. Tariq M., Wright DJ., Bruce TJA \& Staley JT. (2013A). Drought and Root Herbivory Interact to Alter the Response of Above-Ground Parasitoids to Aphid Infested Plants and Associated Plant Volatile Signals. PLOS ONE, 8. $\square^{*}$

48. Tariq M., Rossiter JT., Wright DJ. \& Staley JT. (2013B). Drought alters interactions between root and foliar herbivores. Oecologia, 172, 1095-1104. $\square^{*}$

49. Tariq M., Wright DJ., Rossiter JT. \& Staley JT. (2012). Aphids in a changing world: testing the plant stress, plant vigour and pulsed stress hypotheses. Agricultural and Forest Entomology, 14, 177-185. $\square^{*}$

50. Verdugo JA., Sauge MH., Lacroze JP., Francis F. \& Ramirez CC. (2015). Droughtstress and plant resistance affect herbivore performance and proteome: the case of 
bioRxiv preprint doi: https://doi.org/10.1101/2020.06.24.168112; this version posted December 10,2020 . The copyright holder for this preprint (which was not certified by peer review) is the author/funder, who has granted bioRxiv a license to display the preprint in perpetuity. It is made available under aCC-BY-NC 4.0 International license.

964 the green peach aphid Myzus persicae (Hemiptera: Aphididae). Physiological Entomology, 40, 265-276.

966

51. Wade RN., Karley AJ., Johnson SN. \& Hartley SE. (2017). Impact of predicted precipitation scenarios on multitrophic interactions. Functional Ecology, 31, 16471658.

969

52. Warrington S. \& Whittaker JB. 1990. Interactions between sitka spruce, the green spruce aphid, sulfur-dioxide pollution and drought. Environmental Pollution, 65, 363370. *

53. Xing GM., Zhang J., Liu J., Zhang XY., Wang GX. \& Wang YF. (2003). Impacts of atmospheric $\mathrm{CO} 2$ concentrations and soil water on the population dynamics, fecundity and development of the bird cherry-oat aphid Rhopalosiphum padi. Phytoparasitica, 31, 499-514.

54. Xie H., Shi J., Shi F., Wang X., Xu H., He K. \& Wang Z. (2020). Aphid fecundity and defences in wheat exposed to a combination of heat and drought stress. Journal of Experimental Botany, 71, 2713-2722 *

981

55. Yule KM., Woolley JB. \& Rudgers JA. (2011). Water availability alters the tri-trophic consequences of a plant-fungal symbiosis. Arthropod-Plant Interactions, 5, 19-27. * 